\title{
Entrevista com Oswaldo de Camargo
}

\author{
Ligia Fonseca FerReira \\ Universidade Federal de São Paulo (Guarulhos, Brasil)
}

\begin{abstract}
RESUMO: EM 1990, ENTREVISTEI, EM DOIS MOMENTOS, O ESCRITOR OSWALDO DE CAMARGO. INTERESSADA NAS FORMAS ENUNCIATIVAS DO "EU-NEGRO", O OBJETIVO ERA LEVANTAR DADOS E REGISTRAR A VOZ DO ESCRITOR EM EVOCAÇÕES DE PERÍODOS ANTERIORES E POSTERIORES À SUA CHEGADA A SÃO PAULO, ONDE SE TORNOU UMA REFERÊNCIA E UM ELO ENTRE GERAÇÕES. NESTA ENTREVISTA INÉDITA, QUE CONTA COM A PARTICIPAÇÃO DO POETA PAULO COLINA, CAMARGO FALA DE SUA FORMAÇÃO, DAS ASSOCIAÇÕES NEGRAS, DE CRISES EXISTENCIAIS, DE "MALUNGOS" NEGROS E BRANCOS, DE SUA FÉ E DO LUGAR DE UM ESCRITOR NEGRO NA LITERATURA BRASILEIRA.
\end{abstract}

ABSTRACT: IN 1990, I CONDUCTED TWO INTERVIEWS WITH THE WRITER OSWALDO DE CAMARGO. INTERESTED IN THE WAYS IN WHICH THE "BLACK-I" WAS ENUNCIATED, MY GOAL WAS TO GATHER DATA AND RECORD THE CAMARGO'S VOICE AS HE EVOKED HIS LIFE BEFORE AND AFTER HIS ARRIVAL IN SAO PAULO, WHERE HE BECAME BOTH A SEMINAL FIGURE AND A LINK BETWEEN DIFFERENT GENERATIONS. IN THIS UNPUBLISHED INTERVIEW, IN WHICH THE POET PAULO COLINA ALSO PARTICIPATES, CAMARGO DISCUSSES HIS FORMATIVE YEARS, THE BLACK ASSOCIATIONS TO WHICH HE BELONGED, HIS EXISTENTIAL CRISES, THE BLACK AND WHITE "MALUNGOS" HE KNEW, HIS FAITH AND THE POSITION OF BLACK WRITERS IN BRAZILIAN LITERATURE.

PALAVRAS-CHAVE: LITERATURA NEGRA, ESCRITORES NEGROS BRASILEIROS, OSWALDO DE CAMARGO.

KEYWORDS: BLACK LITERATURE, AFRO-BRAZILIAN WRITERS, OSWALDO DE CAMARGO. 


\section{[Parte 1 $]^{1}$}

IGIA Ferreira: Como foi sua chegada a São Paulo e seu contato com associações negras?

Oswaldo de Camargo: Foi em 1954, eu tinha dezessete, dezoito anos. Trazia na bagagem um livro de poemas, Vozes da Montanha, com sonetos e primeiras tentativas de verso livre, que nunca foi publicado. Tive imensa sorte de chegar a São Paulo numa época em que as associações negras tinham uma vida muito dinâmica, na procura da respeitabilidade tão almejada pelo negro. Quando um negro tinha uma consciência racial, frequentava algumas das diversas associações aqui existentes: a Associação Cultural do Negro (ACN), a Associação dos Patriotas, a José do Patrocínio, a Luiz Gama etc. Por razões circunstanciais, passei a frequentar a ACN. Ficava num ponto central - no décimo-sexto andar do Edifício Martinelli e nelas se encontravam alguns dos velhos militantes, àquela altura beirando os 50-60 anos: José Correia Leite, Jayme Aguiar, o pai da Teodosina Ribeiro, o Tenente Rosário etc. Graças a essas pessoas, o ambiente era ideal para um jovem poeta que desejava ver reunidas algumas tradições ou lembranças de uma literatura negra que porventura tivesse acontecido. José Correia Leite e Jayme Aguiar, os dois maiores patriarcas da Imprensa Negra, encontravam-se também entre os fundadores da ACN. Foi uma grande sorte conhecê-los pessoalmente, ouvi-los de viva voz, ver e tocar o corpo deles, observar a postura e o discurso daqueles "pretos velhos" tão falados e testemunhar como alguns jovens tentavam dar continuidade ao trabalho deles. Aquilo me impressionou muito, pois eu sempre vivera num ambiente de brancos.

Porém, o ambiente da ACN era extremamente conservador. Os velhos tinham medo absoluto, não queriam que falássemos de política. $\mathrm{O}$ objetivo era conquistar respeitabilidade para nós, e nosso comportamento não poderia dar margem a qualquer repreensão ou agressão por parte dos brancos. Esse "bom comportamento" era básico. E eu correspondia a esse padrão na época. É preciso dizer que a década de 50 foi um momento maravilhoso, um dos melhores para o Brasil e para a literatura. Sob este aspecto, não havia perigo. Receava-se o que aconteceu na década de 30 [com a Frente Negra Brasilei-

1. Realizada em 14/01/1990. 
ra]. De repente, lá está uma associação particularista, ostentando o nome "negro", instalada no Prédio Martinelli, com pouquíssimos recursos, e seus membros não querem perder essa tranquilidade. Organizam-se saraus musicais. Era mais fácil conseguir respeitabilidade ouvindo boa música, fazendo recitais de poesia, promovendo conferências, do que permitir que jovens mais afoitos começassem a discutir política. Creio, portanto, que, muito mais que a dos poetas Eduardo de Oliveira, Carlos Assunção, ou ainda outros que ali apareciam, a presença daquele jovem bem magrinho que, com 18 anos era organista, pianista, e fazia versos parnasianos quando queria e versos de circunstância quando pediam, quase na hora, representou, na época, a possibilidade de ele se tornar um escritor respeitável. Para o Correia Leite, um negrinho que tocava músicas clássicas ao piano era um fato extraordinário. Fui praticamente o primeiro pianista que apareceu nesse ambiente negro. No conto "Oboé", em $O$ carro do êxito, retrato um pouco isso tudo.

$\mathrm{Na} A C N$, encontrei-me ainda com autores como o poeta Eduardo de Oliveira, quase 10 anos mais velho do que eu. Um negro publicando livros parecia-me a coisa mais extraordinária do mundo. Lembro-me bem da impressão que me causou na infância um jogo de cartas da [editora] Melhoramentos em que você casava autores parnasianos, românticos, como Alberto de Oliveira, Olavo Bilac, com as respectivas obras. Ainda menino, ganhei um jogo desses e, casando cartas, soube da existência do Cruz e Sousa. Fiquei espantadíssimo de descobrir um poeta negro no Brasil, no meio de vários outros nomes. Eu tinha uns oito anos, estudava num seminário em Bragança Paulista.

\section{Ligia Ferreira: Você tinha livros em casa?}

Oswaldo de Camargo: Não, eu não morava em casa, mas no Preventório Imaculada Conceição de Bragança. Na verdade, meu contato com Correia Leite, Jayme Aguiar e Geraldo Campos de Oliveira, um jornalista da época, reforçava dentro de mim alguns vislumbres acerca da possibilidade de uma escrita negra, através da leitura de Cruz e Souza, das minhas buscas literárias no seminário...

Ligia Ferreira: Que tipo de busca? 
Oswaldo de Camargo: A que está contida no meu [primeiro] livro [Um homem tenta ser anjo]. Eu me considero, talvez, um dos poucos poetas [negros] que praticaram o romantismo, simbolismo, parnasianismo.

Ligia Ferreira: Mas qual o significado desse "praticar" o romantismo, o simbolismo, o parnasianismo? Eram paixões literárias, "exercícios de estilo" ou as únicas correntes que você conhecera até ali?

Oswaldo de Camargo: Creio que isso se deve à minha formação de seminarista, cuja educação, mais rígida, se inicia pelos grandes clássicos. À medida que ia me interessando mais por literatura, pensei: "preciso conhecer mais", e então comecei a estudar toda a Antologia Nacional de Fausto Barreto e Carlos de Laet, obra que, por sinal, formou muito escritor, e me deu um conhecimento das escolas literárias que eu comecei a praticar. Ao mesmo tempo em que eu era conservador, desde Um homem tenta ser anjo sou um escritor livre das peias da rima, das amarras do verso fixo, porque essa obra já é livre, já é moderna, com influência de Drummond, Sá Carneiro, Manuel Bandeira. Nesse sentido, eu era uma novidade quando apareci na ACN.

\section{Ligia FerReira: Que outras recordações você guarda da $A C N$ ?}

Oswaldo de Camargo: Lembro-me que tinha três salas - uma saleta, uma maior com piano e com uma mesa de pingue-pongue, e um outro lugar bem pequenininho -, os velhos sentados vendo a juventude "tentando fazer" alguma coisa. E entre aquilo que se "tentava fazer", o respeito maior era para a literatura, porque a luta dos velhos foi com a palavra através de jornais, da Imprensa Negra dos anos 1920-1930, dos discursos, manifestos etc. Passei bom tempo com eles. Porém, muita gente do meu tempo ou já se foi ou acabou se distanciando do convívio com as associações negras. Muitos companheiros desta batalha inicial, depois de dez anos, diziam "não quero mais saber, a gente não ganha nada com isso" ou, então, "lidar com o negro é a pior parada". Aí, por uma sorte - pelo menos interpreto assim - ou, talvez, por eu ter tido vocação religiosa e ter sido renegado em um seminário como negro, depois de me dizerem claramente que eu não podia ser padre, mantive-me fiel aos grupos que frequentei. 
Ligia Ferreira: Como foi essa bistória de não poder se tornar um padre porque era negro?

Oswaldo de Camargo: Diziam que o negro era muito "violento" e "sensual". Era muito forte essa ideia de o negro ser um homem imprevidente, irresponsável, com uma dose de sensualidade muito maior do que o branco. Não havia coisa pior para a vida religiosa fundada na castidade. Eram os exageros da época. Não há nenhuma justificativa evangélica, pelo contrário. Cristo não viu diferença nenhuma [...] Então me diziam: "Aceitar, nós até aceitamos, mas a sociedade é que não vai entender”. Eu fui obrigado, morando em Poá, a estudar em São José do Rio Preto, no Seminário Menor Nossa Senhora da Paz, dirigido por padres holandeses que me aceitaram. Antes de ir para lá, foram várias tentativas em São Paulo, São Roque, Pirapora, mas ninguém me aceitava. Em Rio Preto, recebíamos uma formação de padres seculares, que só faz dois votos: castidade, obediência. Se tiver posses, pode conservá-las. No meu caso, eram apenas duas calças curtas e um paletó de brim. Os holandeses eram Agostinianos da Assunção, uma ordem fundada na França.

\section{Ligia Ferreira: Por que desistiu do que parecia ser sua vocação? Como se sentiu depois?}

Oswaldo de Camargo: Na verdade, tive uma crise tremenda por volta dos dezessete anos, fiquei doente, magérrimo, não falava com ninguém, fugi do seminário num dia de exame. Os padres achavam que os poetas produziam imagens de erotismo, queriam proteger-nos de tais contaminações. Até os dezessete anos eu só tinha lido antologias. Um dia encontrei um livro de poesias do Alberto Oliveira. Saí do seminário no dia do exame de grego, passei a cerca, andei alguns quilômetros com o livro debaixo do braço, sentei-me à sombra de uma paineira e li o livro na íntegra. Acabei de ler o livro, voltei para o seminário, e já tinha passado o exame de grego. Eu tinha feito uma coisa terrível: li um livro inteiro de poesia. Era proibido. Mas a decisão de sair do seminário foi o maior drama da minha vida. Não sei se atravessarei uma fase tão dura como aquela, sem saber como fazê-lo, pois me achava, de fato, responsável espiritualmente por muita gente. Se os próprios padres não me tivessem dito "saia!", eu não teria saído nunca. Esperei alguém me dizer "saia!". Creio ter transferido em parte esse apostolado para a literatura. Minha 
"militância literária" tem algo de religioso. Penso que cada vez que se cria uma coisa bela no mundo, sem perceber, estamos influindo em tudo. Uma frase de Georges Bernanos me tocou muito: “o Mal que você pratica, não sabe na cabeça de quem vai cair...". Pode ser na cabeça de um inocente qualquer, sem você saber. E o Bem, deve ser a mesma coisa. Quando se cria então um pouco de Beleza no mundo, através da literatura, da música, mudamos o mundo. É uma grande força, a Beleza. Quantas amizades, quanta coisa a gente não faz por causa da literatura. Quanta coisa se solidifica, e também quando você se desentende com um companheiro, reflete e é obrigado a rever sua atitude, seu estar no mundo... Tudo isso é muito instigante.

Ligia Ferreira: Além das atividades na ACN, do que você vivia quando chegou à capital?

Oswaldo de CAmargo: Em 1955, não era exatamente um emprego, comecei como organista na Igreja do Rosário dos Homens Pretos [no Largo do Paissandu]. Tocava em todas as missas, acompanhando uma cantora bem velhinha, com uma voz linda. Adorava missa de réquiem, naquele tempo dedicada a um defunto só. Hoje, se eu morrer e tiver missa, meu nome vai sair no meio de um monte de gente (risos). O vigário era o Padre Garcez, irmão do governador Lucas Garcez, e ele me chamava de "Sinfônico": "Olá, Sinfônico! Como vai, Sinfônico?”. Ganhava trinta cruzeiros por missa, saía da Igreja, ia até a rua Líbero Badaró, na livraria Teixeira, para comprar meus livrinhos no sebo. Foi assim que comecei minha coleção (hoje volumosa. Orgulho-me de minha biblioteca que já prestou serviço a muitos pesquisadores, especialmente estrangeiros). Conhecia todos os livreiros do Centro. Muitos ainda se encontram lá; os mais antigos se lembram de mim, são meus amigos. Então, como além de escritor eu era pianista, deram-me cargo de diretor cultural da ACN: preparava um coral, fazia recitais de poesia na capital e no interior, organizava "Noite de Cruz e Sousa", "Noite de Luiz Gama" etc. O ano de 1955 foi também quando entrei como revisor no jornal O Estado de S. Paulo.

Ligia FERREIRA: Quando se conhece um pouco sua trajetória, fica evidente o lugar de exceção - para não dizer de solidão - que você ocupou, ocupa ainda, na paisagem literária brasileira. Lembrei-me muito de Oswaldo de Camargo quando, no final dos anos 80, durante um Salão 
do Livro na França, o Brasil enviou vinte escritores brasileiros. Houve várias palestras e encontros com o público. Numa delas, levanta-se um rapaz negro, antilhano, e pergunta: "O Brasil é um país com uma grande população negra e mestiça. Por que não há escritores negros entre vocês?". Foi constrangedor ver três escritores (um deles, uma mulher) empurrando o microfone um para o outro, até que alguém dá uma resposta rápida sobre os efeitos da escravidão etc. e tal. Tive sentimentos confusos, uma vergonha albeia. Aquela minha angústia e súbita mudez̧, de não poder me levantar e dar uma explicação àquela gritante estranbeza, foram talvezo ponto de partida para eu mudar de rumo nas minhas pesquisas, voltando para as nossas coisas mais interessantes. Estudar nossa história e nossa literatura tornou-se uma necessidade profunda para uma tomada de consciência. No outro sentido também, além de o negro ter de estudar e conhecer profundamente sua bistória, deve se voltar também para a construção das elites brasileiras, do discurso sobre o negro, sobre a questão racial, dos que condenam e dos que defendem. É preciso compreender historicamente a formação de uma mentalidade.

Oswaldo de Camargo: Você toca num ponto que eu sempre levei muito a sério. Eu tive consciência disso e então sempre procurei instigar o branco a falar sobre a gente, porque quando se faz uma pergunta aos nossos intelectuais, eles não respondem, porque o negro nunca fez parte do pensamento deles realmente. Ele está ali, mas nunca passou pela cabeça deles [...] Tentei sempre, apresentando meu texto para um prefaciador, geralmente intelectuais de peso, independentemente das suas ideias. Meu primeiro livro tem uma breve apresentação, na orelha, do Sérgio Milliet, e prefácio de José Pedro Galvão de Sousa, católico praticante e professor de ética na PUC; outro livro foi prefaciado por Luís Martins, grande economista d'O Estado de S. Paulo. Numa hora dessas, vê-se que, de fato, o número de intelectuais negros ainda é pequeno, não havia possibilidade de se contar com opiniões de intelectuais negros de peso. Você não encontra críticas de um intelectual negro como o Fernando Góes que, ao ver meu livro, O carro do êxito, entusiasmou-se e prometeu um ensaio detalhado, mas não fez. Então, por que é que eu me exponho mais? Por causa da idade, porque sou jornalista, estou inserido num contexto propício.

Ligia FERREIRA: Qual foi a opinião de Florestan Fernandes sobre sua obra?

Oswaldo de Camargo: Ele faz uma crítica no prefácio, importantíssimo, do livro 15 Poemas Negros. Num viés mais sociológico, diz que seria apreciável se 
eu transpusesse uma certa orientação. É que, na ACN, imitávamos a sociedade branca reproduzindo códigos que nos pareciam pautar a respeitabilidade que almejávamos. Havia um coral com repertório basicamente europeu; eu escrevia letras em português para músicas do folclore holandês, alemão etc. E quando poetas como a Nair Araújo ou o Bélsiva declamavam, eu fazia um fundo de piano. Era essa a crítica do Florestan Fernandes: nossa maneira de tentar uma libertação do negro prendia-se a formalismos, segundo ele, a serem superados. Essa libertação só viria a acontecer nos anos 60, quando a África inicia seus movimentos de independência.

Ligia FerReira: Sua atuação como jornalista n'O Estado de São Paulo permitiu-lhe travar amizade com escritores e intelectuais renomados. Uma figura importante parece ter sido o Sérgio Milliet. Como se conheceram?

Oswaldo de Camargo: Quando chego a São Paulo, logo começo a me inserir na vida intelectual da cidade, independentemente do jornal. Com o Sérgio, batia longos papos no Paribar; ele me encorajou muito, deu-me preciosos conselhos.

LIGIA FERREIRA: Vários intelectuais brancos frequentavam a ACN, não?

Oswaldo de Camargo: Sim, aliás, é bem provável que eu tenha conhecido o Sérgio Milliet lá. Além dele, iam o Florestan Fernandes, o Henrique L. Alves, o Roger Bastide, o Afonso Schmidt, um monte de gente [...].

Ligia Ferreira: No caso do Sérgio Milliet, um grande crítico literário, observa-se que no Diário Crítico ele busca sempre atenuar o preconceito racial no Brasil, às vezes afirma coisas quase contraditórias sobre o assunto. Muitos escritores ou intelectuais brancos dizem que negro no Brasil não tem que fazer literatura negra, tem de fazer literatura brasileira. Ou então perguntam: "literatura negra"? Mas quem é negro no Brasil? Que critério usar para dizer se uma pessoa é ou não negra? No que a literatura do negro seria diferente da literatura do branco?

Oswaldo de Camargo: O que pode justificar tudo isso são os bons textos. Porque tem o seguinte: escritor bom é aquele que é lido. Parece brincadeira, mas pre- 
cisamos pensar nisso. Se examinarmos a história de alguns autores negros, vemos que foi importante a amizade com certos brancos: Cruz e Sousa com o dono da Magalhães \& Companhia, que editou Broquéis, o Machado e seus amigos na Academia etc [...]. Hoje, talvez estejamos perdendo algo importante que foi esse relacionamento. Essa troca com o branco acontecia ainda nos anos 1950 a 1970. Nos meus lançamentos todos, quem ia? Lygia Fagundes Telles, Paulo Bonfim, Sérgio Milliet, Florestan Fernandes, Guilherme de Almeida etc [...].

\section{Ligia Ferreira: A que se deve essa perda?}

Oswaldo de Camargo: Perdeu-se porque, de repente, com os movimentos de independência da África, com os movimentos norte-americanos, há uma geração, com talentos, é certo, mas que se orienta de modo diferente, estabelece uma separação mais entre os mundos negro e branco.

Ligia Ferreira: Como, então, você definiria seu projeto a fim de não imitar uma "literatura branca"? O que faz a especificidade de uma literatura negra no Brasil, uma vez. que aqui não se reúnem condições comparáveis à das literaturas afro-americanas ou das Antilhas francesas, por exemplo?

Oswaldo de Camargo: Em primeiro lugar, não se trata de "imitar" a literatura branca $[\ldots]$.

Ligia Ferreira: Sim, mas essa é a visão formada, às vezes, pelo próprio crítico, como o Florestan [...]. Realmente, não sabemos o que se quer dizer com a recomendação de "não imitar a sociedade branca", quando, na verdade, somos brasileiros e brasileiras acima de tudo $[\cdots]$.

Oswaldo de Camargo: O que importa não é imitar ou não, é ser. Se você é de fato um escritor, você vai escolher aquilo sobre o que você tem algo a dizer, ou, senão, se você é premido a escrever sobre aquilo. Note bem: eu acho difícil que um escritor negro já nasça escrevendo como um escritor negro, porque a sociedade começa por jogá-lo dentro da vala comum, de modo que ele não tem, de fato, uma identidade. A grande força da literatura reside no fato de você estar sempre exercitando maneiras de adquirir identidade. Identidade 
é uma coisa muito confusa. Eu não me posso contemplar como brasileiro sem "contaminações" brancas [...].

Ligia Ferreira: O mesmo talvez valha para o brasileiro branco, oriundo de outras regiões, que não está isento de influências africanas e/ ou indigenas, assim como, se for um paulista de origem alemã, se sentirá por aquelas matrizes bem como pelas culturas italiana, japonesa etc.

Oswaldo de CAmargo: A questão começa porque, quando eu falo da minha alma, falo com a mesma língua de Camões, de Sá de Miranda, de Pessoa [...].

Ligia Ferreira: Sim, esse dado é fundamental. Os autores negros brasileiros escrevem em língua portuguesa, a matéria-prima compartilhada por todo escritor brasileiro; não é o créole dos escritores antilhanos de expressão francesa, não é o Black English. O escritor negro brasileiro, penso eu, não vai se espelhar, buscar inspiração mitológica, literária, nos romances africanos, antilhanos, afro-americanos. É primeiro aqui mesmo no Brasil, como o disse Paulo Colina que "despertou" para a problemática do negro lendo Coelho Neto.

Oswaldo de Camargo: O grande drama do escritor negro é que, para ser lido como "negro", se é o que deseja, é obrigado a fazer um exercício mental, racionalizar e escolher "eu vou escrever, falar enquanto negro". Não é uma coisa normal. Um branco brasileiro se senta e escreve sobre um tema, está tranquilo em relação a este, vai direto ao que ele deseja escrever, fala de seu mundo naturalmente. Aí aparece uma coisa perigosíssima. Ao mesmo tempo em que sou escritor, desejo, com a minha palavra, empreender uma luta social. Vou querer transformar o mundo com minha palavra, resgatar minha memória com minha palavra, historiar tudo aquilo que não foi historiado com minha palavra. Será preciso um esforço gigante para dar conta de todas essas frentes num texto. Além do esforço, há o talento e também as circunstâncias que permitam realizar tal projeto. Por outro lado, não posso garantir que, quando escrevo, vou tratar de uma experiência típica de um negro. Quanto ao branco, ele cria automaticamente e apresenta seu mundo, mundo de que é dono, é senhor. Nosso exercício é, às vezes, um tanto artificial. Só um ótimo escritor consegue esconder esse artifício. É essa a palavra. Trata-se de um artifício. Para não deixá-lo à mostra, tem de ser um bom "fingidor", 
do contrário se desmantela. Creio que a maior parte dos escritores negros não logrou desmantelar o artifício. Essa proposta - tornar-se um escritor "negro" - desafiou e desafia muita gente. E muitos não serão escritores porque se propuseram a ser um escritor negro. Essencial, antes de ser negro, é ser, de fato, escritor. Essa é a grande meta. A grande meta não é ser negro, não é a temática negra, mas, sim, ter um projeto que exija o mesmo esforço quer seja você branco, negro, de origem japonesa etc. A diferença é que enfrentamos questões históricas seriíssimas. Estivemos cindidos. Somos pessoas cindidas. Quando me pergunto o que eu sou na verdade, percebo que estou dividido em vários compartimentos. Estou vislumbrando escrever um romance de geração, no qual desejo privilegiar minha vivência de negro, minhas relações com o homem branco, com a mulher branca, com a criança branca e, também, naturalmente, com os meus. Pois bem: a partir do momento em que decidi tratar esse assunto, precisei fazer escolhas, ou seja, fazer um recorte no meu mundo, na minha vivência de homem negro, porque eu sou não sei quantos por cento branco também, pois terei de privilegiar um assunto. Como me preparo para isso hoje? Trocando ideias com meus amigos, especialmente com Abelardo Rodrigues e Paulo Colina ${ }^{2}$, lendo Cruz e Sousa, Lino Guedes, Solano, enfim, sondando dentro de mim mesmo minhas angústias de ser negro: até que ponto sofro por causa de minha cor, até que ponto não. Busco compreender como posso permanecer católico dentro de uma igreja com uma história tão terrível [...].

LigIA FERREIRA: Você nunca sofreu a sedução das religiões afro-brasileiras? Nos discursos atuais, elas aparecem como um elemento importante da "identidade negra", tal como se quer boje.

Oswaldo de Camargo: No meu caso, o catolicismo é uma herança de família. Sou de uma região, Bragança Paulista, onde, como quase em todo Estado de São Paulo não havia esta "sedução" quando eu nasci. Algumas famílias negras estavam muito ligadas ao espiritismo kardecista, minha mãe vez ou outra ia a

2. Camargo refere-se aos jovens amigos poetas Abelardo Rodrigues (1952) e Paulo Eduardo de Oliveira (Paulo Colina), este último nascido em 1950 e falecido em 1999, nove anos depois de concedida esta entrevista. 
um Centro Espírita. De resto, toda família negra e pobre da minha cidade frequentava a Igreja Católica, o catecismo. Àquela altura, não se via em São Paulo o candomblé e outros cultos afro-brasileiros disseminados como hoje. Agora, a pergunta trágica: por que, já aos seis anos, eu brigava para ir ao catecismo? As irmãs nos davam frutas, davam até presentes. Mas pouco importa os motivos pelos quais eu ia ao catecismo. Resulta que fui impregnado desde pequeno. Minha família recebeu apoio dos vicentinos que deram a casa onde meus pais moravam depois de um acidente sofrido por meu pai. Eu poderia rever minha relação com a fé católica, religião é uma coisa para se rever. Mas no que me diz respeito, esta relação cada vez mais se aprofundaria. Era a minha realidade. Àquela altura, não estou interessado e discutindo questões raciais. Mais tarde, já em São Paulo, aos vinte e poucos anos, atravesso outra crise (adoro crises). Se a meta do homem é a felicidade, integrando-se aos próximos e aos mais distantes dele, será que a religião integra de fato? Estava mergulhado num ambiente totalmente contrário aos princípios e valores que eu aprendera, convivendo com intelectuais ateus, gente que xingava a Igreja, fazia muita coisa esquisita. E eu no meio deles, lá na Biblioteca Municipal. O pessoal não respeitava nada, ainda ria de mim porque eu usava um distintivo de congregado mariano na lapela, ia à missa e comungava todos os dias. Era o grupo dos Desagregacionistas, entre 61-62, que bradava "Nós somos os derradeiros filhos de um Deus em decadência”, do qual participavam Jorge Mautner, Jairo Arco e Flecha, Hilda Hilst, entre outros. Eu era o único negro, o único que não bebia pinga (risos). Aliás, meu primeiro uísque tomei com o Sérgio Milliet. Encontro-me nesse meio quando bateu a crise. Conheci a família da Cândida Jardim, família tradicional, fui morar com eles depois de o médico me aconselhar a sair de casa, do contrário continuaria mal. Era solteiro, com mil problemas em casa. A Cândida, que era dona de uma casa enorme na rua Tagipuru e dava pensão para estudantes da PUC, adorava os rapazes e detestava as moças. Ela me acolheu excepcionalmente na casa dela por uns tempos. Todo fim de semana havia saraus com gente da PUC; sempre apareciam pessoas interessantes por lá. Percebendo o meu estado, a Cândida me indicou o nome de um psicólogo na Paulista para eu fazer psicodrama. Era muito comum a classe média mandar o menino ou a menina fazer psicodrama quando ia mal na escola. E eu também fui fazer (risos). Paguei um dinheirão! Cheguei, sentei na frente do médico que examinou meu rosto e começou a falar. Uma das coisas que até hoje guardo, e talvez explique a razão de 
eu continuar católico, foi ter ouvido: "você parece, você é uma cachoeira, tem forças enormes, mas está se dispersando demais e isso não pode". Marcou-me ainda ele dizer que eu era uma pessoa "unilateral": "você tem de quebrar essa unilateralidade. Aprenda línguas, não seja funcionário público etc., etc.” Recebi vários conselhos. E o que tem isso a ver com o fato de eu ter continuado religioso? Uma das explicações seria esse jeito "unilateral" e a crença racional de que Deus nos permite pensar como homens. Como sou muito unilateral e sei que não terei a vida toda, quis levar a fundo minha experiência com a religião católica. A caridade, o amor, é difícil pôr em prática. Leva tempo. É uma religião "ocidental", mas até que ponto não sou "ocidental" também? Eu sou um negro ocidental. O africano também é ocidental. Teve contato com Roma e Grécia muito antes de Cristo. E encontramos no rosto de certos africanos as marcas de colonização de outros países. E não aquela ideia racista presente nos desenhos e ilustrações dos livros didáticos mostrando aquele negro bem boçal, com um nariz bem achatado, um lábio bem grosso, pintado de vermelho na cartilha. Nada disso. Não se pode dizer que o outro padrão é mais bonito. O padrão estético é ditado por quem tem o poder e o impõe. Hoje, são as mídias. Agora aí entra o mistério do meu contato com Deus, um contato em que se deve ter humildade. Não sei quantas situações de minha vida foram criadas por Deus. Mas percebi claramente que em muitas delas eu não posso penetrar. É um tricô: os amigos, a mulher, os filhos que você tem, as palavras que pronuncia. Deixar o melhor de si para, depois que a gente morrer, ser lembrado como uma pessoa bacana, que espalhou e despertou o Bem.

$$
* * *
$$

\section{[Parte 2] $]^{3}$}

Ligia Ferreira: Os anos 1960, conforme podemos ler em alguns de seus contos ("Negritude", "Negrícia")4, foram marcantes, talvez se possa dizer um "divisor de águas" entre o

3. Realizada em 07/02/1990. Deste breve encontro, participou também o escritor Paulo Colina.

4. Textos que integram a coletânea $O$ carro do êxito (São Paulo: Martins, 1972). A esse respeito, ver também Ligia Fonseca Ferreira, "Negritude", "Negridade", "Negrícia": história e sentidos de três conceitos viajantes". In: Via Atlântica, n. 9, 2006, p. 162-183. 
que existira ali como discurso negro presente na Imprensa Negra, em autores, além de você, como o Eduardo Oliveira. Para onde apontam as tendências que se seguem a esse momento?

Oswaldo de CAmargo: É verdade que o grosso da Imprensa Negra realizouse antes do processo de descolonização das colônias africanas, fato que enseja uma nova visão do negro sobre si mesmo, antes do "grito" que poderíamos situar em 1978-79 (criação do MNU - Movimento Negro Unificado, abertura política no Brasil etc.). Nesse período surgem os Cadernos Negros que traz uma voz nunca ouvida, uma novidade descaradamente, gritantemente negra, no qual escreverão poetas muito mais incisivos, que valorizam sua condição racial, colocam novas temáticas com maior virulência. Fica muito clara a postura, se comparada a de Eduardo de Oliveira ${ }^{5}$ que, apesar de bastante presente nas associações negras, no seu livro de lançamento, Além do pó [1958], não tem ainda, conforme apontei ${ }^{6}$, um comprometimento com uma escrita negra, não se afirma nem se coloca com essa contundência, fato de que poderia ter melhor utilizado depois, quando ele se lança na carreira política. De início, então os Cadernos Negros, independentemente de quem escreveu, da qualidade dos textos, que vêm se aperfeiçoando, traz essa nota, este contexto absolutamente negro. Por que isso acontece? Porque àquela altura, ou melhor, até um pouco antes, a África para nós era um sonho. Não conhecíamos africanos, não ressoava ainda o grito "black is beautiful (negro é lindo)", nem todas as ex-colônias africanas haviam se tornado independentes, as de língua portuguesa só em meados da década de 1970. Quando surgiu um dos primeiros países independentes, o antigo Congo Belga, eu fiz a matéria de capa com o retrato de Patrice Lumumba na revista Níger. Esses movimentos na África foram um marco, refletem-se no nosso pensamento e na nossa literatura. Acontece uma coisa incrível: de repente, o negro se expõe muito mais, quer saber o que se passa em outros lugares. É verdade que, desde os anos 50, tínhamos - eu e Correia Leite - um pouco mais de familiaridade, de admiração pelos americanos, até porque, de modo geral, recebia mais influência dos Estados Unidos em vários aspectos. Então, sob influência dos movimentos

5. Nascido em São Paulo, em 1926, Eduardo Oliveira é autor também de Gestas Líricas da Negritude (1967), entre outros.

6. Ver Oswaldo de Camargo. O Negro Escrito. Apontamentos sobre a presença do negro na literatura brasileira. São Paulo: Imprensa Oficial do Estado de São Paulo, 1987. 
africanos, é que também o negro brasileiro passa a se afirmar como mais negro, mesmo não conhecendo a África. Aquela primeira Imprensa Negra realiza coisas sempre considerando uma perspectiva histórica brasileira. Os autores do Cadernos Negros ampliam essa visão, olham para outros horizontes que definem de modo diferente esse "eu" negro.

Ligia FERreira: Em diversas ocasiões, você comentou sentir uma certa solidão, uma falta de pessoas com quem dialogar sobre suas vivências, seus projetos, e isso, apesar da sua "popularidade".

Oswaldo de Camargo: Sim, é verdade. Talvez esse sentimento tenha originado meus ataques, um tanto virulentos e anticristãos, ao Eduardo de Oliveira, um escritor um pouco mais velho do que eu e com o qual eu desejava ter estabelecido uma maior cumplicidade. Meu grande apoio, meu grande papo, minha grande cerveja, deveria ter sido com o Eduardo de Oliveira, o homem com quem eu deveria poder trocar figurinhas sobre nossa condição de escritores, pessoas, acontecimentos, coisas do tipo "como é que foi mesmo há dez anos?” etc. Talvez ele tenha sido arrastado pela ânsia de ser alguém, abraçando a política, em detrimento da literatura, da posição que sonhávamos para ele.

Ligia Ferreira: Hoje, essa interlocução se dá com o Abelardo Rodrigues e o Paulo Colina e os três, ao que parece, são companheiros de tal modo inseparáveis que já foram batizados pelo Arnaldo Xavier de "triunvirato". Paulo, como se dá o encontro de vocês?

Paulo Colina: Eu conheci o Oswaldo por volta de 1977. Em 1975, eu tinha começado a escrever meus primeiros textos. Eu trabalhava nas proximidades da Consolação e, na hora do almoço, frequentava a Biblioteca do SESC Consolação. Uma bibliotecária de lá, não sei por que cargas d'água incentivou-me a participar de um concurso de contos. Participei, fiquei entre os finalistas, e os organizadores acabaram me convidando para participar de uma das primeiras oficinas literárias realizadas em São Paulo. Ajudei na coordenação junto com um argentino, Mário Jorge Lescano (que depois até faria parte do grupo fundador do Quilombhoje). Além da oficina, criamos o Asterisco, um suplemento literário do SESC, onde eu publiquei meus contos dali em diante. O Lescano tornou-se um grande amigo, gostava de rodar a cidade como eu. Costumava passar pelo 
bar conhecido como Buraco da Antonieta, que fica numa passagem da 7 de Abril para a Praça Dom José Gaspar. Ficava num subsolo, uns 2 andares abaixo do térreo. A Antonieta era uma garçonete muito simpática, todo mundo gostava muito dela. Atualmente mudou de dono e se chama o Bar do Alípio [...].

Oswaldo de Camargo: Ah, perdeu a graça! (risos).

Paulo Colina: O jornal O Estado de S. Paulo ficava ali em frente, na rua Martins Fontes, e o Oswaldo de Camargo passava sempre por lá. Eu notava aquela figura de terno azul-marinho, uma gravatinha fininha, um braço cheio de livros, uma pasta do outro lado. Um dia o Lescano me diz: "olha, eu conheci um escritor negro, como você". Porque na época eu escrevia meus contos buscando inserir uma visão, um ponto de vista negro. Eu era o único que havia coordenado a oficina literária e publicado no Asterisco. Um dia, estava com o Lescano no Buraco da Antonieta e, de repente, vem o Oswaldo, desce correndo as escadas e, enquanto ele desce, o Alípio serve rápido um copo de leite no balcão [...].

Oswaldo de CAMARgo: Que vergonha! ...

Paulo Colina: [...] o Lescano nos apresentou e, de cara, o Oswaldo me deu um livro dele, $O$ carro do êxito, tomou o copo de leite e saiu voando para o jornal. Esse foi o meu primeiro encontro com o escritor, com a pessoa Oswaldo de Camargo, cujos textos, cuja personalidade, me encantaram.

Ligia Ferreira: Uma curiosidade: o titulo $\mathrm{O}$ carro do êxito tem algo a ver com $\mathrm{O}$ carro da miséria (contos), de Mário de Andrade?

Oswaldo de CAmargo: Há sem dúvida uma influência de O carro da miséria, quis traçar um paralelo. Primeiro ia colocar como título "O carro do sucesso", mas quis evitar um galicismo, afinal eu era revisor d'O Estadão. Por fim, Carro do Exxito me pareceu bem [...].

Paulo Colina: Quanto ao “triunvirato”, um outro aspecto interessante é termos personalidades e formações distintas. É esse diálogo que buscávamos, eu e o Abelardo Rodrigues, que é de São José dos Campos. Encontramo-nos 
amiúde, trocamos figurinhas, temos também muitas opiniões divergentes. Porém o Oswaldo tinha o que, logicamente, nenhum de nós tinha: essa visão de mundo, essa ligação com sua comunidade, uma posição definida enquanto homem, negro, brasileiro, cidadão "dono" mundo. Pensamos nossa condição como escritores, como negros, como escritores negros.

Ligia Ferreira: Minha hipótese é de que, se não existisse o Oswaldo de Camargo, a configuração da literatura negra hoje seria outra. Você é para muitos e, incontestavelmente, uma ponte, um elo entre gerações.

Oswaldo de Camargo: O que posso dizer é que minha idade me habilita hoje a ser uma espécie de intermediário entre os jovens de hoje e os velhos que me confiaram sua herança. Minha fidelidade à literatura e a todas essas histórias que vivi, ouvi ou presenciei, faz de mim uma espécie de "lembrador" para os que vieram depois de mim, do que ocorreu antes deles. Sou aquele que vai lembrar. Por outro lado, simbolizo uma certa miséria do negro em geral, pois se nossa condição fosse outra (do ponto de vista social, educativo, econômico), não haveria "um" Oswaldo de Camargo, haveria quatro, cinco escritores negros ou mais. É evidente que estamos hoje num outro Brasil, com outro tipo de relacionamento inter-racial e, também, quando se diz "pobre", referimo-nos a uma boa parcela da população negra e mulata. Tinha a esperança de que, quando chegássemos nos anos 1960, 1970, 1980 houvesse mais do que a minha presença. Acaba sendo uma responsabilidade grande e perigosa o fato de eu me tornar um porta-voz praticamente único e incontestável. Não tive interlocutores na minha geração. Uma das coisas de que eu mais me orgulho não são meus livros, meus escritos, pois não cabe a mim avaliar. Orgulho-me de ser esse elo entre as pessoas, entre gerações. Devido a minha relação estreita e persistente com a literatura e com a comunidade negra (um Fernando Góes, desalentado, acabou abandonando), fui a ligação com poetas espalhados pelo Brasil. Quem procurou o gaúcho Oliveira Silveira fui eu. Tenho documentos provando isso. Um amigo me falou de um escritor negro em Porto Alegre, eu quis saber quem era, descobri o endereço, mandei carta e um livro meu. Depois me falaram também de um escritor em Minas Gerais, o Adão Ventura. Foi a mesma coisa. E tantos outros, Ele Semog, no Rio. Aqui, em São Paulo, havia o Paulo Colina e o Abelardo Rodrigues. Com eles formava um núcleo. 
Paulo Colina: Aliás, por essas e outras afinidades, tornamo-nos companheiros, como já escreveu o Oswaldo, de "alma e de literatura". ${ }^{7}$ E juntos alimentamos nossa maior utopia, ou seja, acreditar que um dia nossos livros, nosso trabalho por inteiro, poderão ser inseridos à literatura brasileira sem o rótulo "negra" ou "afro-brasileira".

Recebido em 10 de julho e aprovado em 15 de setembro de 2010.

7. Ver dedicatória do livro O Negro escrito, op. cit., p. 5. 